\title{
Putative mechanisms of bacterial effects on plant photosystem under stress
}

\author{
O. P. Burlak ${ }^{1}$, J.-P. de Vera', V. Yatsenko³, N. O. Kozyrovska ${ }^{1}$ \\ ${ }^{1}$ Institute of Molecular Biology and Genetics, NAS of Ukraine \\ 150, Akademika Zabolotnoho Str., 150, Kyiv, Ukraine, 03680 \\ ${ }^{2}$ Space Research Institute, DLR, Rutherfordstr. \\ 2, D-12489 Berlin, Germany \\ ${ }^{3}$ Institute of Space Research of NASU/NSAU \\ 40, Akademika Hlushkova Av., Kyiv, Ukraine, 03680 \\ burlak.oleksii@gmail.com
}

\begin{abstract}
Bacteria are micro- and nanoorganisms that spatially colonize the plant organism and comprise various types of interactions with the host ranging from pathogenic to mutualistic and symbiotic. The presence of these exo- and endosymbionts may affect the plant host physiology. Non-pathogenic bacteria can enhance defensive capacity in plants that provides protection against phytopathogens and herbivores, as well as makes a valuable contribution to the protection of plants from abiotic stressors. Endophytes demonstrate the protection of photosystem in plants under environmental challenges. The putative mechanisms of bacterial effects on plant photosystem are discussed in this paper.
\end{abstract}

Keywords: bacteria, photosystem, abiotic and biotic stresses.

Introduction. Plants need energy to drive photosynthesis which converts light energy to chemical energy in the form of energy-rich carbohydrates. Photosynthesis is regulated by environmental factors as well as endogenous sugar signals. Plant-associated bacteria consume plant-derived photosynthates, and this is why steering the photosystem.

A rate of photosynthesis is usually evaluated by measuring chlorophyll (Chl) $a$ fluorescence. In intact leaves at room temperature, the majority of $\mathrm{Chl} a$ fluorescence arises from photosystem II (PSII). The fluorescence yield of PSII is variable as a result of competition between photochemical and non-photochemical processes, and the outcome of this interaction changes $\mathrm{Chl}$ fluorescence yield. Chl $a$ fluorescence measurement has been proven to be a useful non-invasive tool for the study of different aspects of photosynthesis, and for the quantification of any stressor impact in plants [1]. Interaction of

(c) Institute of Molecular Biology and Genetics, NAS of Ukraine, 2013 microorganisms (beneficial or pathogenic) with plants leads to complex alterations in fluorescence, and the conclusions that can be drawn about the metabolic processes underlying the interactions are limited. A number of parameters can be calculated from $\mathrm{Chl} a$ fluorescence measurements that can, with caution, be related to changes in the photosynthetic apparatus of the host under an impact of microorganisms.

$\mathrm{Fv} / \mathrm{Fm}$ - the maximum quantum yield of PSII photochemistry - is one of the most common fluorescence measurements which shows the efficiency of light absorbance by the pigment matrix associated with PSII when all PSII centres are in the open state [2]. An estimate of the PSII maximum efficiency is provided by $F v / F m$ in the dark-adapted state and $F v^{\prime} / F m^{\prime}$ in the light-adapted state [3]. The $F v / F m$-value may serve as an indicator of plant stress and can be measured quickly on dark-adapted leaves. The parameter $\Phi_{\mathrm{PSII}}$ is the operating efficiency of PSII when illuminated. At very low irradiance levels, this will be close to $F v / F m$, but as 
irradiance increases, values of $\Phi_{\mathrm{PSII}}$ will fall, and energy is dissipated by non-photochemical processes. $q P$ photochemical quenching - coefficient reflects the capacity of reaction centers to compete for $\mathrm{Chl}$ excited states, and it is related to the redox state of primary quinone acceptor of PSII $\left(Q_{A}\right)$. In the case where all reaction centers are open and capable of photochemistry, $q P$ is maximal (estimated as 1), and the fluorescence yield is low. However, when reaction centers are closed due to reduction of $Q_{A}, q P$ is zero, and fluorescence yields are maximal. $N P Q$ - Stern-Volmer non-photochemical quenching - is a measure of heat dissipation and reflects the combination of photo-protective mechanisms. $N P Q$ is affected by non-photochemical quenching that reflects heat-dissipation of excitation energy in the antenna system [2]. So it may be thought of as an indicator of «excess excitation energy». In this paper we provide the data on impact of microorganisms, including endophytic bacteria, on PSII efficiency and discuss putative mechanisms of endophytic bacterial effects on the plant photosystem.

Impact of phytopathogens on PSII efficiency. Data on the effect of phytopathogens on PSII efficiency are widely represented in the literature. A spectrum of plant host responses to the attacks of pathogens, ranging from complete susceptibility to complete resistance, allows suggesting that not a single pattern of responses will emerge. A typical host response observed in plant-fungal interactions is an initial reduction in $F v / F m$ and $\Phi_{\text {PSII }}$, but an increase in $N P Q$. At the later stages of infection, all these parameters decline as the photosynthetic apparatus is destroyed. In necrotrophic infections, these effects will appear quickly, whilst in biotrophic infections, the impacts on steady-state values of $\Phi_{\text {PSII }}$ and $N P Q$ often become apparent only at the later stages of infection when visible symptoms appear. The impairments of photosynthesis associated with biotrophic infections include the reduction in photosynthetic pigment contents and maximum quantum yield of PSII photochemistry. Pathogens may also produce the toxins that have direct or indirect effects on photosynthetic metabolism or the compounds that act as plant growth regulators. In oat leaves infected with Puccinia coronata (crown rust), there was a small and highly localized reduction in $\Phi_{\mathrm{PSII}}$ as the first symptoms became visible on a leaf 5 days after infection [4]. How- ever, $N P Q$ was strongly reduced across the entire leaf with marked changes in the pattern observed during photosynthetic induction, which is thought to reflect a leaf-wide increased demand for ATP. As the infection progressed, both $\Phi_{\mathrm{PSII}}$ and $N P Q$ were much reduced in the areas of visible symptoms. A similar leaf-wide reduction in $\Phi_{\text {PSII }}$ was found in lupine infected with the necrotroph Pleiochaeta setose [5]. In contrast, wheat leaves infected with the hemibiotroph Mycosphaerella graminicola showed a typical localized decline in $F v / F m$, a decline in $\Phi_{\mathrm{PSII}}$ and an increase in $N P Q$ in the vicinity of developing necrotic lesions [6].

In common with many plant-fungal interactions, the reduction in $F v / F m$ and $\Phi_{\text {PSII }}$ was also a result of infection by pathogenic bacteria and viruses [7]. More specifically, a diminution of $F v / F m$ and $\Phi_{\text {PSII }}$ was seen in leaves of bean (Glycine max) infected with avirulent Pseudomonas syringae pv. glycinea, although little effect was caused by the virulent strain that elicited a hypersensitive reaction. In the study on the ArabidopsisP. syringae pathosystem, Matous et al. [8] and Berger et al. [9] found that $F v / F m$ and $\Phi_{\mathrm{PSII}}$ declined upon infection along with an initial rise in $N P Q$ followed by a decline. Bonfig et al. [10] examined the infection of Arabidopsis thaliana by virulent and avirulent strains of $P$. syringae pv. tomato DC 3000 and found that in both strains infection led to a localized decline in $F v / F m$, $\Phi_{\text {PSII }}$ and $N P Q$ before symptoms were visible by eye.

Effect of non-pathogenic microorganisms on photosynthetic apparatus has been shown in a set of studies. Transcriptome analysis of Arabidopsis plants colonized by a plant-growth promoting rhizobacterium Pseudomonas thivervalensis revealed a low level of transcripts related to photosynthesis, and the real photosynthesis rates were repressed consistently with the reduced growth of plants colonized by the bacterium. Interestingly, the plants treated with $P$. thivervalensis were more resistant to subsequent infections by the virulent pathogen $P$. syringae pv. tomato DC3000 than the control plants. In this case, the down-regulation of photosynthesis is thought to be only a transient effect needed for the production of other transcripts necessary for the conditions of colonization and priming plants for fast response against phytopathogen [11].

A smashing effect was discovered by Zhang with co-authors [12] in Arabidopsis plants exposed to Ba- 
cillus subtilis colony at a distance, without physical contact with plant roots: they showed that the bacterium elevated the photosynthesis level through the modulation of endogenous sugar/abscisic acid (ABA) signaling and established its regulatory role in the photosynthetic activity. The studies revealed the elevation of endogenous sugar accumulation in the plant, suppression of classic glucose signaling responses, and overlap in sugar/ABA sensing with suppression of ABA-biosynthetic transcripts. The authors explain such effect by sustained volatile signaling emitted by the bacterium. The volatile-triggered plants exhibited also the increase of salt [13], as well as osmotic tolerance [14]. It is not excluded that the bacterium triggered the plant also indirectly, via endophytic microbial residents which sensed its signals at a distance.

Very little is known about the physiological interactions between plants and endophytic bacteria in the respect of effect on photosynthesis. Shi et al. [15] investigated the impact of three endophytic bacteria species, Bacillus pumilus, Chryseobacterium indologene, and Acinetobacter johnsonii, on the photosynthetic capacity of sugar beet (Betula vulgaris). The measurements of total chlorophyll content revealed very significant differences between non-inoculated beet plants and those inoculated with endophytic bacteria. The maximum photochemical yield was significantly higher for endophyte-inoculated than control plants. It is possible that the increased $F v / F m$-value in sugar beet was promoted by phytohormones produced by the bacteria. In another study, microarray technique revealed that endophytic bacterium Burkholderia phytofirmans PsJN differentially influenced the activity of genes responsible for photosynthesis in different potato cultivars [16]. Thus, the challenge inoculation of potato cultivar Russet Burbank, where bacteria promoted plant growth, resulted in the down-regulation of a number of genes for photosynthesis, and vice versa in cultivar Bionta where their expression was up-regulated on the background of poor plant growth.

Alleviating photoinhibitory stress by endophytic microorganisms. Non-optimal temperature, salinity, drought, irradiation cause stresses in plants, leading to the disturbance of homeostasis and impairment of photosynthesis. Environmental stress enhances the extent of photoinhibition, a process that is determined by the balance between the rate of photodamage to PSII and the rate of its repair. The recent investigations suggest that the exposure to environmental stresses does not affect photodamage but inhibits the repair of PSII through suppression of the synthesis of PSII proteins [17]. To deal with stresses, plants have evolved several defense mechanisms. Maximum quantum yield is an indicator of a stress under various conditions [18] but efficient quantum yield is more sensitive at water stress and high light [19], salinity [20] or freezing [21].

Marks and Clay [22] measured the photosynthetic rate and leaf conductance of 13 genotypes of tall fescue (Festuca pratensis) infected by endophytic fungus Neotyphodium coenophialum and revealed that at temperature $35^{\circ} \mathrm{C}$, stressful for this plant species, the noncolonized endophyte-free plants photosynthesized at a significantly lower rate $(20 \pm 25 \%)$ than the infected plants. Inoculation of garlic plants (Allium sativum L.) with mycorrhizal Glomus fasciculatum was found to be more promising to induce plant growth under lower and moderate salinity levels. Mycorrhiza protected the plants against salinity injury by increasing photosynthetic activity and biomass content [23]. The exposure of an endophytic fungus Piriformospora indica that colonizes the roots of many plant species to Arabidopsis seedlings under mild drought stress for $84 \mathrm{~h}$ showed that the photosynthetic efficiency was only slightly reduced in the colonized and was severely impaired in the non-colonized seedlings [24]. The $F v / F m$ value indicated that photosynthesis performance in the non-colonized seedlings was severely impaired. This demonstrates that the root-colonized seedlings suffered from drought stress less than the non-colonized controls.

Endophytic bacteria, exogenously applied for both plant inoculation, as well as resident ones, possess a potency to alleviate the effect of stressors on PSII [25]. In our project, the photosynthetic efficiency of PSII complexes of Crassulacean Acid Metabolism plant Kalanchoe daigremontiana Hamet \& Perr. inoculated with endophytic bacteria Methylobacterium sp. IMBG290 was assessed under ambient and stressful conditions (low atmospheric pressure, high $\mathrm{CO}_{2}$ concentration, and UVB) [25]. The stressful conditions were simulated inside the experimental facility [26] where the specimens of Kalanchoe plants were placed. The fiberptic fluorometer was mounted in the experimental chamber, 


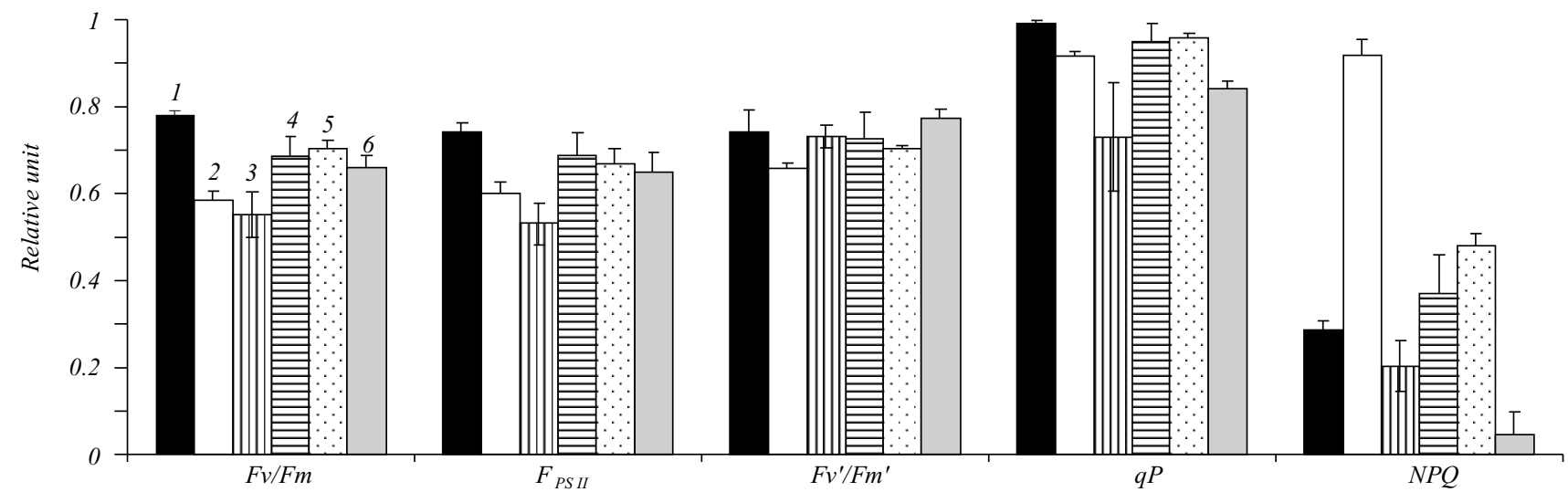

The maximum quantum yield $(F v / F m)$, the efficient quantum yield $\left(\Phi_{\text {PSII }}\right)$, the PSII maximum efficiency $\left(F v^{\prime} / F m^{\prime}\right)$, the photochemical quenching $(q P)$, the non-photochemical quenching $(N P Q)$ of the Kalanchoe daigremontiana plants under stressful conditions $(1-$ non-inoculated outside MSF; 2 - non-inoculated inside MSF; 3 - P. fluorescence; 4-Paenibacillus sp.; 5 - Methylobacterium sp.; 6 - all bacteria). Error bars indicate the SD of the means $(n=3)$. Kalachoe plants treated with various bacterial strains. Plants lighted with light-emitting diode (LED) during a day period under conditions; control plants were grown inside the facility and without stressful conditions

so that the maximum quantum yield of PSII and other parameters were measured under stress in situ, within the facility. Chl $a$ fluorescence measurement under stressful low pressure and high concentration of $\mathrm{CO}_{2}$ in the experimental camera showed positive impact of the Methylobacterium sp. pretreatment on Kalanchoe plants which was seen as higher $F v / F m$ and $\Phi_{\text {PSII }}$ values (Figure). In contrast, the plant treatment with Pseudomonas sp. led to the decrease of $F v / F m$ value under the same conditions. In both cases the effect of bacteria was associated with a day-time phases of PSII activity and reflected an increase in ribulosebisphosphate carboxylase/oxygenase (Rubisco)-mediated daytime $\mathrm{CO}_{2}$ uptake while it was not relevant to phosphoenolpyruvate carboxylase-mediated night-time $\mathrm{CO}_{2}$ uptake.

Putative mechanisms of plant protection under assistance of endophytic microbial communities. $A c$ tivating resident endophytic community as a response to environmental stress. Diverse endophytes occupy econiche in the plant interior and interact with the plant partner under their life-span as mutualists or commensals without deleterious effects on the plant system [27]. Often endophytes reside within the phytoendosphere latently until being activated by the environmental signals [28-30].

Culture techniques traditionally used to characterize the endophytic ensemble often show rather limited size of populations and diversity of microbes residing within specific plant tissues, however, a range of species isolated from different higher plants, sphagnum and fern allows the conclusion that a spectrum of endophytic bacteria is wide [31]. Culture-independent molecular-based techniques and high-throughput pyrosequensing revealed an incredible level of endophytic populations in the plant partner [32,33]. This permits to accept the plant-microbial ecosystem as a superorganism where endophytic microbes might be active players in plant physiology.

Endophytes, being in intimate contacts with the plant partner, impact the plant defensive system and endow the tolerance to heavy metals, radiation, etc. [25, $31,34]$. Endophytic bacterial communities, known as dynamic systems, are influenced by both internal (genetically determined plant metabolism and associated microbiota) and external (environmental signals) factors. The changes in bacterial endophytic communities reflect the current plant physiological state and development phase, as well as the effect of the plant-microbe system surrounding. Fluctuations in bacterial populations may mean that in the core microbiome, some populations are being activated or fallen into unculturable or VBNC (viable but-non-culturable) state, even quenched, giving their metabolites and space for successive populations within the period of plant vegetation. Under necessity, for example, under some external threat, the endophytic bacterial community can be mobilized by some external stimulus and rise a size of their populations [28, 29, 35]. Activating endophytic residents coincided with the better survival of potato vitroplants under post vitro conditions and this may serve as an in- 
direct preliminary evidence that resident endophytes invest in the immune response [36, 37]. We can postulate that resident endophytic bacterial communities (as well as other endophytic microorganisms) have a potency to modulate the plant protection system against external threat. A respond occurs in plants triggered by an elicitor when resident microbial populations have a certain level of activity (competency), size and potency in defensive reaction. Mechanisms of endophytic communities defensive performance are expected to be various: the activation of the plant reactive oxygen species (ROS)detoxification system and complementation with its own antioxidant systems, antagonism, the induction of a systemic disease resistance via hormone-dependent signaling pathways, synergistic action with epiphytic commensals, a quorum-like mechanism of synchronization of the plant microbiome by the incoming bacteria.

Protection against oxidative stress. In all phases of photosynthesis in the light period all plants are subjected to oxidative stress when photorespiration is performed. Vigorous photosynthetic $\mathrm{CO}_{2}$ assimilation due to high internal $\mathrm{CO}_{2}$ concentration behind closed stomata also generates high internal $\mathrm{O}_{2}$ concentrations. Chlorophyll triplets are known to readily react with oxygen to produce ROS. Photodamage process leads to the impairment of PSII electron transport and induction of D1 protein degradation [38]. Endophytic inhabitants possess a variety of own non-specific tactics to defend against the production of ROS, as well as nitric oxide, and phytoalexins. For example, the genome of endophytic Klebsiella pneumoniae 342 encodes mechanisms to protect itself against these three plant defense mechanisms. There are three superoxide dismutases, four putative catalases, 6 putative peroxidases, 1 hydroperoxide reductase, and 12 putative glutathione-S-transferase that can defend the cell against ROS [39]. The activation of plant ROS-detoxification system by resident endophytes may be a way to protect plants against toxic effects of ROS.

The antioxidant systems serve as the first barrier against pathogen invasion compared to the defense genes that are activated upon pathogen attack. For example, the pre-treatment of Arabidopsis plants with endophytic bacterium Methylobacterium sp. IMBG290 activated ascorbate peroxidase, superoxide dismutase, catalase, guaiacol peroxidase [36].
We can assume that due to this bacterium (probably, in concert with a resident endophytic bacterial community) the elimination of ROS, actively formed in leaf tissues in stressful conditions, occurred more efficiently than in untreated plants, and this process may protect photosynthetic centers.

Improving the PSII electron transport. The fluorescence yield of PSII is a result of competition with photochemical and non-photochemical processes. Non-photo chemical quenching $N P Q$ transforms into heat the excess of light energy that cannot be used in photosynthesis and may lead to the ROS formation. These processes utilize the recovered molecules of ATP and NADPH that cannot be used in photosynthesis. A high value- $N P Q$ may represent the down-regulation of photosynthetic electron transport.

In bacteria-treated plants, the quantum yield of nonphotochemical dissipation in PSII complexes is reduced as compared to untreated plants $[12,13,25]$. This may mean that there is the fraction of $Q A$, the primary electron acceptor of PSII present in the reduced state, indicating improved electron transport downstream from PSII.

The $N P Q$ is higher in stressed plants than in control plant, exhibiting enlarged de-exciting by thermal dissipation processes [40, 41]. $N P Q$-value rises as a protective mechanism, however, high value- $N P Q$ may represent a down-regulation of a photosythetic electron transport so that the production of ATP and NADPH would match the decreased $\mathrm{CO}_{2}$ assimilation. Under stress, imitating Mars conditions, in situ chlorophyll fluorescence measurement in stressed Kalanchoe leaves pretreated with Methylobacterium sp. showed that nonphotochemical dissipation in PSII antenna complexes was reduced. This may indicate indicating improved electron transport downstream from PSII compared to non-inoculated plants and increased demand for ATP [25]. At the same time, $q P$ of stressed plants decreased as compared to control plants kept under ambient conditions. This supposes the decrease in electron flow through the electron transport chain of PSII and appropriate synthesis of ATP and NADPH. In contrast, pretreated with Methylobacterium sp. plant specimens had higher $q P$ value close to the control (outside of stress) plants value (see Figure). Based on these results, it is possible to assume that the photoprotective role of bacteria was mani- 
fested by the improving of PSII downstream electron flow under model stressful conditions.

Induction of systemic resistance. Another putative mechanism of plant defense against stressors where endophytic populations participate is the induction of systemic resistance. Plant growth-promoting bacteria cause Induced Systemic Resistance (ISR), defined as an enhancement of the plant's defensive capacity against a broad spectrum of pathogens that is acquired after appropriate stimulation/priming [42, 43]. Most reports of the bacteria-mediated ISR involve free-living rhizobacterial strains, but endophytic bacteria have also been observed to have ISR activity [36, 44]. ISR is associated with expression of defense-related genes which are regulated by a network of hormones. In our recent study, endophytic Methylobacterium sp. IMBG290 was capable of priming JA/ET pathway by the up-regulating genes in response to the pathogenic bacterium attack [36]. Microorganisms also induce systemic tolerance to abiotic stressors. Thus, $P$. indica conferred droughtstress tolerance to Arabidopsis, and this was associated with the priming of the expression of a quite diverse set of the stress-related genes in leaves [24].

Conclusions. Photosynthesis is a major physiological function of the plant-microbial ecosystem, giving the energy for every constituent of the system, and, in turn, all of them defend the photosystem via a network of signals, coordinating the operating system. Endophytes attenuate in some range the stressful effects of drought, salt, UV, a combination of high content of $\mathrm{CO}_{2}$ and low atmospheric pressure on plant physiology. $\mathrm{Pu}-$ tative endophyte-mediated mechanisms of photosystem protection under external cues may be different; some of them anticipated the enhancement of hormone-dependent plant defense systems, improvement of PSII electron transport, activation of endophytic microbiome. With caution it can be suggested that these mechanisms depend on the activity and «talents» of endophytic microorganisms at a certain developmental phase of the plant host. The structure of endophytic bacterial communities reflects the current plant physiology state, as well as the impact of the plant-microbe system surrounding. In the core microbiome, some populations are being activated or fallen into the VBNC state or quenched under certain internal messages from the environment. Experimentally derived arguments can provide an im- portant insight into the precise mechanisms of tolerance to abiotic stressors in the endophytosphere via plant microbiome.

The exploring of a concept of the role of endophytic microbial communities in plant protection will contribute to a better understanding the plant tolerance to stressful environmental factors. In this context, the selection of plant genotype/ecosystem with adapted to stresses microbiomes may be favoured in order to protect the plant photosystem under coming climate change challenges or in extraterrestrial greenhouses.

Acknowledgments. This work was supported by Science and Technology Center of Ukraine, grant 5240.

\section{О. П. Бурлак, Ж.-П. де Вера, В. О. Яченко, Н. О. Козировська}

Ймовірні механізми впливу бактерій на фотосистему рослин за умов стресу

Резюме

Бактерії є мікро- і наноорганізмами, які колонізують простір рослинного організму і укладають різні види взаємодій - від патогенних до мутуалістичних і симбіотичних. Присутність иих екзо- та ендосимбіонтів може впливати на фізіологію рослини-господаря. Непатогенні бактерії здатні посилювати у рослин функиії захисту від фітопатогенів і шкідників, а також опірність діi абіотичних стресорів. Ендофіти перешкоджають икідливим ефектам довкілля на фотосистеми рослин. Ймовірні механізми подібного виливу обговорюються у даній статті.

Ключові слова: бактерії, фотосистема, абіотичний $i$ біотичний стреси.

\section{А. П. Бурлак, Ж.-П. де Вера, В. О. Яченко, Н. А. Козыровская}

Возможные механизмы влияния бактерий на фотосистему растений в условиях стресса

Резюме

Бактерии являются микро- и наноорганизмами, колонизирующими пространство растительного организма и формирующими различные виды взаимодействий - от патогенных до мутуалистических и симбиотических. Присутствие этих экзо- и эндосимбионтов может влиять на физиологию растения-хозяина. Непатогенные бактерии способны усиливать у растений функиии зашиты от фитопатогенов и вредителей, а также устойчивость к действию абиотических стрессоров. Эндофиты противостоят вредному воздействию окружающей среды на фотосистемы растений. Возможные механизмы подобного влияния обсуждаются в данной статье.

Ключевые слова: бактерии, фотосистема, абиотический и биотический стрессы.

\section{REFERENCES}

1. Krause G., Weis E. Chlorophyll fluorescence and photosynthesis: the basics // Annu. Rev. Plant Physiol. Plant Mol. Biol.1991.-42.-P. 313-349. 
2. Maxwell K., Johnson G. N. Chlorophyll fluorescence - a practical guide //J. Exp. Bot.-2000.-51, N 345.-P. 659-668.

3. Baker N. R., Rosenqvist E. Applications of chlorophyll fluorescence can improve crop production strategies: an examination of future possibilities // J. Exp. Bot.-2004.-55, N 403.-P. $1607-$ 1621.

4. Scholes J. D., Rolfe S. A. Photosynthesis in localised regions of oat leaves infected with crown rust (Puccinia coronata): quantitative imaging of chlorophyll fluorescence // Planta.-1996.-199, N 4.-P. 573-582

5. Guidi L., Mori S., Degl'Innocenti E., Pecchia S. Effects of ozone exposure or fungal pathogen on white lupin leaves as determined by imaging of chlorophyll a fluorescence // Plant Physiol. Biochem.-2007.-45, N 10-11.-P. 851-857.

6. Scholes J. D., Rolfe S. A. Chlorophyll fluorescence imaging as tool for understanding the impact of fungal diseases on plant performance: a phenomics perspective // Funct. Plant Biol.-2009.-36, N 11.-P. 880-892.

7. Zou J., Rodriguez-Zas S., Aldea M., Li M., Zhu J., Gonzalez D. O., Vodkin L. O., DeLucia E., Clough S. J. Expression profiling soybean response to Pseudomonas syringae reveals new defenserelated genes and rapid HR-specific downregulation of photosynthesis // Mol. Plant Microbe Interact.-2005.-18, N 11.P. 1161-1174.

8. Matous K., Benediktyova Z., Berger S., Roitsch T., Nedbal L. Case study of combinatorial imaging: what protocol and what chlorophyll fluorescence image to use when visualizing infection of Arabidopsis thaliana by Pseudomonas syringae? // Photosynth. Res.-2006.-90, N 3.-P. 243-253.

9. Berger S., Benediktyova Z., Matous K., Bonfig K., Mueller M. J., Nedbal L., Roitsch T. Visualization of dynamics of plant-pathogen interaction by novel combination of chlorophyll fluorescence imaging and statistical analysis: differential effects of virulent and avirulent strains of $P$. syringae and of oxylipins on $A$. thaliana // J. Exp. Bot.-2007.-58, N 4.-P. 797-806.

10. Bonfig K. B., Schreiber U., Gabler A., Roitsch T., Berger S. Infection with virulent and avirulent $P$. syringae strains differentially affects photosynthesis and sink metabolism in Arabidopsis leaves // Planta.-2006.-225, N 1.-P. 1-12.

11. Cartieaux F., Thibaud M. C., Zimmerli L., Lessard P., Sarrobert C., David P., Gerbaud A., Robaglia C., Somerville S., Nussaume $L$. Transcriptome analysis of Arabidopsis colonized by a plantgrowth promoting rhizobacterium reveals a general effect on disease resistance // Plant J.-2003.-36, N 2.-P. 177-188.

12. Zhang H., Xie X., Kim M. S., Kornyeyev D. A., Holaday S., Pare $P$. W. Soil bacteria augment Arabidopsis photosynthesis by decreasing glucose sensing and abscisic acid levels in planta // Plant J.-2008.-56, N 2.-P. 264-273.

13. Zhang H., Kim M. S., Sun Y., Dowd S. E., Shi H., Pare P. W. Soil bacteria confer plant salt tolerance by tissue-specific regulation of the sodium transporter HKT1 // Mol. Plant Microbe Interact.2008.-21, N 6.-P. 737-744.

14. Zhang H., Murzello C., Sun Y., Kim M. S., Xie X., Jeter R. M., Zak J. C., Dowd S. E., Pare P. W. Choline and osmotic-stress tolerance induced in Arabidopsis by the soil microbe Bacillus subtilis (GB03) // Mol. Plant Microbe Interact.-2010.-23, N 8.P. 1097-1104.

15. Shi Y., Lou K., Li C. Growth and photosynthetic efficiency promotion of sugar beet (Beta vulgaris L.) by endophytic bacteria// Photosynth. Res.- 2010.-105, N 1.-P. 5-13.

16. Trognitz F., Scherwinski K., Fekete A., Schmidt S., Eberl L., Rodewald Ya., Schmid M., Compant S., Hartmann A., Schmitt-
Kopplin P., Trognitz B., Sessitsch A. Interaction between potato and the endophyte Burkholderia phytofirmans // Tagung 59 der Vereinigung der Pfl Anzenzuchter und Saatgutkaufleute (Osterreichs, 25-27 November 2008).-Osterreichs, 2008.-P. 63-66.

17. Takahashi S, Murata N. How do environmental stresses accelera te photoinhibition? // Trends Plant Sci.-2008.-13, N 4.-P. 178-182.

18. Percival G. C., Sheriffs $C$. N. Identification of drought-tolerant woody perennials using chlorophyll fluorescence // J. Arboriculture.- 2002.-28, N 5.-P. 215-223.

19. Lu C., Qiu N., Lu Q., Wang B., Kuang T. PSII photochemistry, thermal energy dissipation, and the xanthophyll cycle in Kalanchoe daigremontiana exposed to a combination of water stress and high light // Physiol. Plant.-2003.-118, N 2.-P. 173-172.

20. Debez A., Koyro H. W., Grignon C., Abdelly C., Huchzermeyer B. Relationship between the photosynthetic activity and the performance of Cakile maritima after long-term salt treatment // Physiol. Plant.-2008.-133, N 2.-P. 373-385.

21. Dai F., Zhou M., Zhang G. The change of chlorophyll fluorescence parameters in winter barley during recovery after freezing shock and as affected by cold acclimation and irradiance // Plant Physiol. Biochem.-2007.-45, N 12.-P. 915-921.

22. Marks S., Clay K. Physiological responses of Festuca arundinacea to fungal endophyte infection // New Phytologist.-1996.133, N 4.-P. 727-733.

23. Borde M., Dudhane M., Jite P. K. AM Fungi influences the photosynthetic activity, growth and antioxidant enzymes in Allium sativum L. under salinity condition // Not. Sci. Biol.-2010.-2, N 4.-P. 64-71.

24. Sherameti I., Tripathi S., Varma A., Oelmuller R. The root-colonizing endophyte Piriformospora indica confers drought tolerance in Arabidopsis by stimulating the expression of drought stress-related genes in leaves // Mol. Plant Microbe Interact.2008.-21, N 6.-P. 799-807.

25. Burlak O., Mikheev O., Zaets I., de Vera J.-P., Lorek A., Koncz A., Foing B., Kozyrovska N. Photosystem II of Kalanchoe daigremontiana sheltered by bacterial consortium under Mars-like conditions // Kosmichna Nauka i Tekhnologiya (Space Sci. Technol.).-2011.-17, N 3.-P. 45-53.

26. de Vera J. P., Mohlmann D., Butina F., Lorek A., Wernecke R., Ott $S$. Survival potential and photosynthetic activity of lichens under Mars-like conditions: a laboratory study // Astrobiology.-2010.-10, N 2.-P. 215-227.

27. Kozyrovska N. O. Endophytes.ua.-Kyiv: LAT\&K, 2011.-248 p.

28. Reiter B., Pfeifer U., Schwab H., Sessitsch A. Response of endophytic bacterial communities in potato plants to infection with Erwinia carotovora subsp. atroseptica // Appl. Environ. Microbiol.-2002.-68, N 5.-P. 2261-2268.

29. Podolich O. V., Ardanov P. E., Voznyuk T. M., Kovalchuk M. V., Danylchenko O. V., Laschevskyi V. V., Lyastchenko S. A., Kozyrovska $N$. O. Endophytic bacteria from potato in vitro activated by exogenic non-pathogenic bacteria // Biopolym. Cell.-2007.23, N 1.-P. 21-28.

30. Lian J., Wang Z., Zhou S. Response of endophytic bacterial communities in banana tissue culture plantlets to Fusarium wilt pathogen infection // J. Gen. Appl. Microbiol.-2008.-54, N 2.P. 83-92.

31. Rosenblueth M., Martinez-Romero E. Bacterial endophytes and their interactions with hosts // Mol. Plant Microbe Interact.- 2006.19, N 8.-P. 827-837.

32. Manter D. K., Delgado J. A., Holm D. G., Stong R. A. Pyrosequencing reveals a highly diverse and cultivar-specific bacterial endophyte community in potato roots // Microb. Ecol.-2010.60, N 1.-P. 157-166. 
33. Sessitsch A., Hardoim P., Doring J., Weilharter A., Krause A., Woyke T., Mitter B., Hauberg-Lotte L., Friedrich F., Rahalkar M., Hurek T., Sarkar A., Bodrossy L., van Overbeek L., Brar D., van Elsas J. D., Reinhold-Hurek B. Functional characteristics of an endophyte community colonizing rice roots as revealed by metagenomic analysis // Mol. Plant Microbe Interact.-2012.-25, N 1.-P. 28-36.

34. Zaets I., Kozyrovska N. Heavy metal resistance in plants: a putative role of endophytic bacteria // Toxicity of heavy metals to legumes and bioremediation / Eds A. Zaidi et al.- Wien: Springer, 2012.-P. 203-217

35. Podolich O., Lytvynenko T., Voznyuk T., Kovalchuk M., Kozyrovska $N$. Detection of endophytic bacteria communities in aseptic potato plants after inoculation with Pseudomonas sp. IMBG 163 // Proc. Uzhgorod State Univ.-2006.-N 18.-P. 165-170.

36. Ardanov P., Ovcharenko L., Zaets I., Kozyrovska N., Pirttila A. $M$. Endophytic bacteria enhancing growth and disease resistance of potato (Solanum tuberosum L.) // Biol. Control.-2011.-56, N 1.-P. 43-49.

37. Ardanov P., Sessitsch A., Haggman H., Kozyrovska N., Pirttila A. M. Methylobacterium-induced endophyte community changes correspond with protection of plants against pathogen attack // PLoS One.-2012.-7, N 10.-doi: 10.1371/journal.pone. 0046802.

38. Rintamaki E., Salo R., Lehtonen E., Aro E. M. Regulation of D1protein degradation during photoingibition of photosystem II in vivo: phosphorylation of the D1-protein in various plant groups // Planta.-1995.-195, N 3.-P. 379-386.
39. Fouts D. E., Tyler H. L., de Boy R. T., Daugherty S., Ren Q., Badger J. H., Durkin A. S., Huot H., Shrivastava S., Kothari S., Dodson R. J., Mohamoud Y., Khouri H., Roesch L. F., Krogfelt K. A., Struve C, Triplett E. W., Methe B. A. Complete genome sequence of the $\mathrm{N}_{2}$-fixing broad host range endophyte Klebsiella pneumoniae 342 and virulence predictions verified in mice // PLoS Genet.-2008.-25, N 7.-e1000141.

40. Guralnick L. J., Heath R. L., Goldstein G., Ting I. P. Fluorescence quenching in the varied photosynthetic modes of Portulacaria afra (L.) Jacq. // Plant Physiol.-1992.-99.--N. 4.-P. 1309-1313.

41. Herzog B., Grams T. E. E., Haag-Kerwer A., Ball E., Franco A. $C$., Luttge $U$. Expression of modes of photosynthesis (C3, CAM) in Clusia criuva Camb. in a cerrado/gallery forest transect // Plant Biol.-1999.-1.-P. 357-364.

42. van Peer R., Niemann G. J., Schippers B. Induced resistance and phytoalexin accumulation in biological control of Fusarium wilt of carnation by Pseudomonas sp. strain WCS417r // Phytopathology.-1991.-81, N 7.-P. 728-734.

43. Wei G., Kloepper J. W., Tuzun S. Induction of systemic resistance of cucumber to Colletotrichum orbiculare by select strains of plant growth-promoting rhizobacteria // Phytopathology.1991.-81, N 12.-P. 1508-1512.

44. Conn V. M., Walker A. R., Franco C. M. Endophytic actinobacteria induce defense pathways in Arabidopsis thaliana // Mol. Plant Microbe Interact.-2008.-21, N 2.-P. 208-218. 